On Filipino Philosophy

\title{
The Linguistic Turn as a Political Act: Another Look at the Thoughts of Roque Ferriols
}

\section{Franz Giuseppe F. Cortez}

\begin{abstract}
This paper explores what I would call as the "linguistic turn" of Roque Ferriols, a prominent Filipino philosophy luminary. Following Paulo Freire's notion of the non-neutrality of education, I will argue that Ferriols' linguistic turn can also be read as a political act. Even if he does not have a sustained analysis of the politics of language, there are interspersed texts showing that he is deliberately and consciously involved in the process of critique and problematization of colonial discourse and elitist mentality. Thus, when he is alternatively seen as a participant in a wider discourse of linguistic politics, the readers of Ferriols become more aware of the liberating motive and potential behind his choice of Filipino for philosophizing and for teaching philosophy.
\end{abstract}

Keywords: Freire, Ferriols, politics of language, non-neutrality of education

\section{Introduction}

$\mathrm{R}$ oque J. Ferriols is a Filipino Jesuit priest and a teacher of philosophy at the Ateneo de Manila University, a school that has a long-standing reputation of being the school for elite and affluent Filipinos. He is considered as one of the pioneers of the discipline of philosophy in the 


\section{THOUGHTS OF ROQUE FERRIOLS}

Philippines. ${ }^{1}$ According to Leovino Ma. Garcia, another philosophy teacher at the Ateneo, Ferriols is "the undisputed father of Filipino philosophy." 2

Ferriols is popularly known for his philosophical ruminations on meron, a Filipino word that can ordinarily be translated into English as "has/have," indicators of possessing and/or owning. ${ }^{3}$ However, with the brilliant mind of this Jesuit priest, meron as well as its other forms, pagmemeron and nagmemeron, has transcended its ordinary connotation as Ferriols has discovered the philosophical richness of the word and the meanings it entails. ${ }^{4}$ This paper, however, does not dwell on his philosophy of meron and pagmemeron. Rather, as the title suggests, I will primarily look at his use of Filipino, the national language of the Philippines, in philosophizing and in teaching philosophy. I will argue that this "linguistic turn" 5 can also be read as a political act. By talking about politics, I follow Paulo Freire's lead regarding the non-neutrality of education.

Paulo Freire (1921-1997) is a Brazilian educator, activist and philosopher during the second half of the $20^{\text {th }}$ century. According to Jones Irwin, a Freirean commentator, "Freire's influence on both theory and practice in education has been monumental and, alongside John Dewey, he is perhaps the most significant educational thinker and practitioner of the twentieth century." 6 Then, Donaldo Macedo and Ana Maria Araujo, two

${ }^{1}$ In a philosophical conference sponsored by the Philosophical Association of the Philippines (PAP) entitled "The Legacy Lectures: Engaging Our Philosophical Pioneers," Ferriols was honored as one of the philosophical pioneers. The conference was held on October 26-27, 2012 at De La Salle University, Manila, Philippines. See <http://www.pap73.org/midyearconference2012.html>.

2 Leovino Ma. Garcia, "Fr. Roque J. Ferriols, S.J.," in Loyola Schools Bulletin (November/December 2006), 2. Date Accessed: 16 March 2013, <http://ls.ateneo.edu/global/UserFiles/File/lsb_v02-6-7_nov-dec06.pdf>.

3 "Ang naturang kataga ay madalas gamitin sa pagtukoy sa pag-aari o pag-aangkin. 'Meron siyang anak.' 'May bagong kotse si Dodong.' 'Makakapasok ba ang taong mayroong maraming kwarta sa kaharian ng langit?' 'Si Petra ba'y may kasintahan?'” Roque Ferriols, Pambungad sa Metapisika (Quezon City: Ateneo de Manila, 1991), 132.

${ }^{4}$ The book Pambungad sa Metapisika is Ferriols' attempt to reflect on and explain the philosophy of Meron.

${ }^{5}$ This term is used not in the same sense as "the linguistic turn" initiated by the analytic philosophers at the end of the nineteenth century. This original meaning of linguistic turn revolves on themes of logic and philosophy of the mind. It is usually attributed to the pioneering efforts of Gottlob Frege, Bertrand Russell and Ludwig Wittgenstein. See Michael Wolf, "Philosophy of Language," in Internet Encyclopedia of Philosophy (May 12, 2009.) Date Accessed: 16 March 2013, <http://www.iep.utm.edu/lang-phi/>. The use of "linguistic turn" here should be understood in a very narrow connotation of Ferriols' conscious turn or shift of language to be used in philosophizing and in teaching philosophy.

${ }^{6}$ Jones Irwin, Paulo Freire's Philosophy of Education: Origins, Developments, Impacts and Legacies (London: Continuum, 2012), 12.

(c) 2014 Franz Giuseppe F. Cortez

http://www.kritike.org/journal/issue 14/cortez june2014.pdf

ISSN 1908-7330

(cc) BY-NC 
Freirean scholars, declare the Brazilian as "the most significant educator in the world during the last half of the [twentieth] century." ${ }^{7}$

I will begin by presenting Paulo Freire's notion of the non-neutrality of education. Then, I will discuss the social milieu when Roque Ferriols made the linguistic turn, after which, I will lay down the reasons why Ferriols made the shift on language. Finally, I will show why and how Ferriols' linguistic turn can be read as a political act following Freire's insight on the nonneutrality of education and its instrumentalities.

\section{Paulo Freire's Non-Neutrality of Education}

One of the fundamental themes of Paulo Freire's pedagogical theory is the non-neutrality of education. This non-neutrality is not a distinctive mark of Freire's educational project per se, separating it from other pedagogical enterprise. Rather, he maintains that every educational act is inherently not neutral. In a 1975 essay, he categorically declares: "The first proposition that I advance and the most basic one is that there is nothing like neutral education. Education is a political act." 8

In making this categorical statement, Freire does not mean that the teacher immediately converts the classroom into a political arena where political ideologies take the center stage, political rallies are held, specific political parties are upheld and political mobilizations are planned. He goes beyond the narrow understanding of politics and political as simply the affairs of the government, the politicians, the activists and the militants. In a much later book, Freire clarifies: "Whoever thinks 'it is the work of some educator, more given to activism than anything else' has a very warped notion of what "political' means." 9 That is why he goes back to Aristotle's pronouncement of the human person being a political animal. He says: "As women and men, we continue to be what Aristotle said so well. We are political animals. We continue to be that into which we have turned: political animals."10 The British educator Tristan McCowan says that "Freire uses [politics and political] in the broadest sense, meaning all relations of power and forms of organization in society, whether or not they occur within the domain of official governmental affairs." 11

\footnotetext{
7 Donaldo Macedo and Ana Freire, Foreword to Paulo Freire, Teachers as Cultural Workers: Letters to Those Who Dare Teach (Colorado: Westview, 2005), vii.

${ }^{8}$ Paulo Freire, Education for Liberation (Bangalore: Ecumenical Christian Centre, 1975), 17-18.

${ }_{9}^{9}$ Paulo Freire, Pedagogy of Freedom: Ethics, Democracy and Civic Courage (Maryland: Rowman \& Littlefield Publishers, 1998), 100.

${ }^{10}$ Paulo Freire, Pedagogy of the Heart (New York: Continuum, 1998), 41.

${ }^{11}$ Tristan McCowan, "Approaching the Political in Citizenship Education," in Educate, 6:1 (2006), 59.
} 
Education is non-neutral and political because it is always normatively grounded in specific philosophies, viewpoints, aspirations and interests. In Cultural Action for Freedom, a book that consists of Freire's lectures at Harvard University in 1970, he already highlights the direct connection between the educational practice and its underlying philosophical assumptions. "All educational practice implies a theoretical stance on the part of the educator. This stance implies-sometimes more, sometimes less implicitly-an interpretation of man and the world. It could not be otherwise."12 Thus, from the very conception of an educational program up to its implementation, it is replete with ideas, ideals, visions and choices. These ideals and choices favor some at the expense of others. Hence, these choices are political from the very start.

In another essay, Freire says that "no educational practice takes place in a vacuum, only in a real context-historical, economic, political, and not necessarily identical to any other context." 13 He also reiterates it in Pedagogy of Hope where he says: "There never is, nor has ever been, an educational practice in zero space-time-neutral in the sense of being committed only to preponderantly abstract, intangible ideas." 14 As Joe L. Kincheloe, the founder of the Freire Institute in the United States, would say it simply: "Anytime teachers develop pedagogy, they are concurrently constructing a political vision. The two acts are inseparable."15

In Pedagogy of Freedom, one of the books that Freire wrote in his twilight years, he further clarifies this non-neutrality by connecting the educational process with the unfinishedness of human existence. He explains: "The real roots of the political nature of education are to be found in the educability of the human person. This educability, in turn, is grounded in the radical unfinishedness of the human condition and in our consciousness of this unfinished state." 16 Since the human person is unfinished and he/she is conscious of this, his/her actions are necessarily directive. He/she acts because he/she has dreams, aspirations and ends. The educative act being a human act is directive. "Education as a specifically human action has a 'directive' vocation, that is, it addresses itself to dreams, ideals, utopias, objectives, to what I have been calling the 'political' nature of education." 17

Thus, Freire does not choose to make education political. In a response to questions during one of his lectures at University of London,

${ }^{12}$ Paulo Freire, The Politics of Education: Culture, Power, and Liberation, trans. by Donaldo Macedo (Connecticut: Bergin \& Garvey Publishers, 1985), 43.

${ }^{13}$ Ibid., 12.

${ }^{14}$ Paulo Freire, Pedagogy of Hope (New York: Continuum, 1995), 65.

${ }^{15}$ Joe Kincheloe, The Critical Pedagogy Primer (New York: Peter Lang, 2008), 9.

${ }^{16}$ Freire, Pedagogy of Freedom, 100.

${ }^{17}$ Ibid., 67 and 100.

(c) 2014 Franz Giuseppe F. Cortez

http://www.kritike.org/journal/issue 14/cortez june2014.pdf

ISSN 1908-7330

(cc) BY-NC 
Freire further declares: "Non-neutrality does not depend only on you or on me; it comes from the nature of the process. I would say it is ontological. It belongs to the nature of education." 18 Education "has the inherent qualities to be political, as indeed politics has educational aspects." 19

By openly taking side with the "wretched of the earth," making a stand regarding concrete issues, and letting the student become aware of his/her option, the Freirean educator does not curtail the freedom of the student to choose. "The fact that the educator is not a neutral agent does not mean, necessarily, that he/she should be a manipulator. The truly liberating option is not even realized by means of a manipulative practice. Manipulation is debilitating and, likewise, irresponsible." 20 The critical educators "do not have the right to impose their positions on their students." 21 Imposition is a sign of disrespect for the capacity of the student to decide for himself/herself. It is a violation of what liberating pedagogy stands for: respect for freedom of the student. ${ }^{22}$

Freirean liberating pedagogy cannot violate itself. It gives the students the space to think for themselves: "to compare, to choose, to rupture, and to decide." 23 The Freirean educator proclaims without imposing, declares without indoctrinating or brainwashing, and engages without authoritarianism. It does not "darken" reality through propaganda. It illuminates reality. ${ }^{24}$ Freire says: "It is very interesting because of the contradiction we deal with in liberating education. In the liberating moment, we must try to convince the students and on the other hand we must respect them, not impose ideas on them." 25

And so, one of the main elements of Freire's pedagogical theory is non-neutrality or the politics of education-one that favors the interest of the oppressed. "That is, it must be fundamentally tied to a struggle for a qualitatively better life for all through the construction of a society based on nonexploitative relations and social justice." 26 Giroux sees in Freire a pedagogy "that is partisan to its core, for in its origins and intentions it is for

\footnotetext{
${ }_{18}$ Paulo Freire, "Some Issues: Neutrality, Respect for the Students, Epistemological Curiosity, and International Financial Aid," in Paulo Freire at the Institute, ed. Maria de Figueiredo-Cowen and Denise Gastaldo (London: University of London, 1995), 68.

${ }^{19}$ Freire, The Politics of Education, 188.

20 Paulo Freire and Donaldo Macedo, Literacy: Reading the Word $\mathcal{E}$ the World (Massachusetts: Bergin \& Garvey Publishers, 1987), 39.

${ }^{21}$ Kincheloe, The Critical Pedagogy Primer, 11.

22 Freire, Pedagogy of Freedom, 120.

${ }^{23}$ Ibid., 68.

${ }^{24}$ Paulo Freire and Ira Shor, A Pedagogy for Liberation: Dialogues on Transforming Education (London: MacMillan, 1987), 13.

${ }^{25}$ Ibid., 33.

${ }^{26}$ Peter McLaren, "Critical Pedagogy: A Look at the Major Concepts," in The Critical Pedagogy Reader, ed. by Antonia Darder (London: Routledge, 2003), 70-71.
}

(C) 2014 Franz Giuseppe F. Cortez http://www.kritike.org/journal/issue 14/cortez june2014.pdf ISSN 1908-7330 
choosing life." 27 It is at home with what Max Horkheimer, one of the pioneers of Critical Theory, would regard as the specific and practical aim of critical theory: "to liberate human beings from the circumstances that enslave them." 28

\section{The Social Background of Ferriol's Linguistic Turn}

It was the school year of 1969 when Fr. Roque Ferriols first taught philosophy with Filipino as the medium of instruction. ${ }^{29}$ Montes' article in The Guidon, the Ateneo's newspaper, provides an image of the infancy days of Ferriols' classes in Filipino. Montes says: "The readings in the Philosophy of Man in Pilipino course are in English, but the discussions, lectures, papers, and exams are all in the national language." 30 A 1975 essay of Ferriols will confirm Montes' account. ${ }^{31}$ Garcia even compares Ferriols' choice to the groundbreaking efforts of philosophers such as Rene Descartes and Soren Kierkegaard who also deviated from the normal course of philosophizing by turning their backs from the official language of their times and writing in their own native tongue. ${ }^{32}$

If seen from the context of Philippine education in general and Ateneo de Manila University in particular, Ferriols' choice in 1969 can be considered as a radical and a brave move. It is because during that time, the Philippine academic world was dominated by the English language, by a proAmerican and Americanized education. In the introduction to a festschrift honoring Ferriols, Ateneo philosophy professors Agustin Rodriguez and Nemesio Que have a better way of expressing this domination by the English language:

For a long time, our intellectual life was dominated by English as the only proper expression for the deepest

\footnotetext{
27 Giroux, Teachers as Intellectuals: Towards a Critical Pedagogy of Learning (Massachusetts: Bergin \& Garvey, 1988), 120.

${ }^{28}$ Max Horkheimer, Critical Theory: Selected Essays, trans. by Matthew J. O'Connell (NY: Continuum, 2002), 244.

${ }^{29}$ In 1969, Filipino was called Pilipino. It was just changed to Filipino in 1974. Filipino or Pilipino became one of the official languages alongside English and Spanish when independence was proclaimed in 1946. Filipino was highly based on Tagalog, one of the most prevalent vernacular languages and the language spoken by the residents of Southern Luzon including Metro Manila. Tagalog was changed to Pilipino in 1955. See Clodualdo Cabrera, "The Pedagogical Role of English in the Reproduction of Labor," in Mula Tore Patungong Palengke: Neoliberal Education in the Philippines (Quezon City: Ibon Books, 2007), 201.

${ }^{30}$ Vaughn Montes, "Pilipino Philosophy Course Reveals Important Insights," in The Guidon, (24 November 1969).

${ }^{31}$ Roque Ferriols, "A Memoir of Six Years," in Philippine Studies 22:3-4 (1974), 340.

${ }^{32}$ Garcia, "Fr. Roque J. Ferriols, S.J.," 2.

(c) 2014 Franz Giuseppe F. Cortez

http://www.kritike.org/journal/issue 14/cortez june2014.pdf

ISSN 1908-7330

(cc) BY-NC
} 
discoveries of the human spirit. Philosophy, science, literature-all of them belonged to the domain of the English speaker. Thus, the Filipino thinker was confined to thinking his soul's thoughts in a language born from alien soil. Filipino thinkers were taught not only to read thinkers in a foreign language but also to think their own spirits' insight in the language removed from their

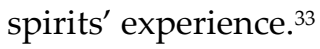

That is why the path that Ferriols chose was not a smooth one. The administration of the Ateneo was bordering on hesitation and disagreement. These are the words of Ferriols:

“...hindi nila [ng administrasyon ng Ateneo] ako binigyan ng oras. Tapos noong sinabi ko, 'Bakit walang oras?' 'Kasi,' sabi nila, 'volunteer class yan, kaya kailangan mag-meeting kayo at mag-desisyon kayo kung kailan ang oras.' Pero siyempre, kung walang oras na nakatakda, wala nang panahon na maiiwan. Pero noong panahon na iyon may lunch break sa tanghali na walang klase. Kaya naisipan kong magkaroon ng klase doon sa panahon ng lunch break." 34

Obviously, these words from Ferriols show the cold acceptance or even the possible rejection by the Ateneo administration of Ferriols' plan to hold philosophy class in Filipino. An article from the university's newspaper The Guidon, written by Jose Luis Alcuaz, an Ateneo student during that time, corroborates this further. Alcuaz asks:

...why is it that the philosophy courses in Pilipino and the Tagalog composition course of the Linguistics Department might be cancelled if they do not have at least 20 and 15 students, respectively? Haven't courses in English and classics gone on with fewer than a dozen students? A matter of practicality? We hope that the

${ }^{33}$ Agustin Rodriguez and Nemesio Que, Introduction to Pagdiriwang sa Meron: A Festival of Thinking Celebrating Fr. Roque J. Ferriols, S.J., ed. by Agustin Rodriguez and Nemesio Que (Quezon City: Ateneo de Manila University, 1997), vi.

${ }^{34}$ Roque Ferriols, "An Interview with Ferriols," in University Traditions: The Humanities Interviews, ed. by Ramon Sunico (Quezon City: Ateneo de Manila University Press, 2005), 190. 


\section{THOUGHTS OF ROQUE FERRIOLS}

new administration will get the proper insight into the matter of priorities. ${ }^{35}$

Then, here is how Rodriguez and Que think of Ferriols' situation during those days of 1969 :

Of course, there was great resistance. The administration did not immediately recognize the validity or value of classes in Filipino, so these were called experimental and kept away from prime time. It is difficult to take philosophy classes in Filipino seriously then and even now, when a good knowledge of English facilitates the commerce of the world. ${ }^{36}$

The last years of the 1960s also marked the era of the re-vitalization of the intense issue of Filipinization of the religious orders in the Philippines. ${ }^{37}$ This issue of Filipinization was undeniably linked with nationalist consciousness and mobilizations. In the context of the Filipino priests, the core of Filipinization is in their dream of being recognized in their talents and potentialities by giving them vital and high positions not only in the schools owned by the religious orders but also in the highest offices of the religious congregations in the Philippines. In the context of the experience of the Ateneans and the Filipino Jesuits, this is what Joaquin Bernas, an eminent Jesuit priest had to say: "the call for Filipinization is [a] call for an Ateneo with a more Filipino face." 38

Ferriols was one of the staunchest supporters of Filipinization. From the perspective of Ramon Reyes, a philosophy teacher of the Ateneo and also an eyewitness to the said issue, the point of the Jesuit advocates of Filipinization such as Fr. Bonoan, Fr. Bernad and Fr. Ferriols is similar to this: "Of course we don't really hate you [American Jesuits], but this is now the time that the Filipinos must take over, not only in this school, but in the

\footnotetext{
${ }^{35}$ Jose Alcuaz, "Students Robbed of Moral Victory," in The Guidon, (24 November 1969).

${ }^{36}$ Rodriguez and Que, "Introduction," v.

${ }^{37}$ In a study done by a Filipino Dominican priest Rolando Dela Rosa, formal and deliberate moves towards the "Filipinization of the Orders" had started as early as 1957 when six Filipino priests from different religious congregations wrote to the Vatican to ask for a recognition of the ability of the Filipino priests to lead the religious Orders in the Philippines. For a more detailed discussion, see Beginnings of the Filipino Dominicans (Quezon City: Dominican Province of the Philippines, 1990), 198ff.

38 Joaquin Bernas, "A View from the Hill at 145," <http://www.admu.edu.ph/ index.php?p=502.>, 5 November 2012.
} 
[Jesuit] province." ${ }^{39}$ In an interview with Garcia, he believes that Ferriols was already pro-Filipino in words, thought and action even before the height of the Filipinization movement. Garcia says: "Of course even before [the Filipinization Movement], the real 'Filipinist' on campus was Fr. Ferriols. That may not be well known now, but even before it broke out, he was the one striving to bring out the quest for Filipino identity." 40

Besides the controversial issue of Filipinization, the second half of the 1960s was also the era of social unrest in the Philippines. Several groups were formed to protest against the administration of Ferdinand Marcos, the country's president then, who eventually put the whole nation under martial law. ${ }^{41}$ Many schools, teachers and students participated in various mobilizations to oppose Marcos and to promote radical changes in the country's social, economic and political structures..$^{42}$ Inspired by the ideology of Marx, Lenin and Mao, a young journalist by the name of Jose Maria Sison re-established the Communist Party of the Philippines (CPP) in December $1968 .{ }^{43}$ The following year, its armed group, the New People's Army (NPA) was also formed.

Students, teachers and priests from the Ateneo de Manila were also actively engaged in this call for radical social transformation. On November 27, 1968, the famous "Down from the Hill" manifesto was published in The Guidon. The said manifesto was penned by five Ateneo students, namely Jose Alcuaz, Gerardo Esguerra, Eman Lacaba, Leonardo Montemayor and Alfredo Salanga. They were afterwards known as "The Big Five." 44 In the said manifesto, "The Big Five" courageously declares that the Philippine nation is already in a revolutionary state. ${ }^{45}$ They call for radical conversion of the Jesuit priests. They demand for the Filipinization of the Ateneo.

39 Ramon Reyes, "An Interview with Ramon Reyes," in University Traditions, 235.

40 Leovino Ma. Garcia, "An Interview with Leovino Ma. Garcia," in University

${ }^{41}$ Daniel Schirmer and Stephen Shalom, eds., The Philippines Reader: A History of Colonialism, Neocolonialism, Dictatorship and Resistance (Cambridge: South End, 1987), 163ff.

42 Cf. Corazon Damo-Santiago, A Century of Activism (Manila: Rex, 1972), 106-197. Damo-Santiago reports the involvement of many students from various schools in different street protests, rallies and demonstrations during that time.

${ }^{43}$ Jan Fermon, "Who is Jose Ma. Sison," in Jose Ma. Sison: A Celebration, ed. by Production Group, Aklat ng Bayan (Quezon City: Aklat ng Bayan, 2011), 147.

${ }^{44}$ Jose Magadia, "The Political Landscape of the '70s and Some Jesuit Responses to the Changing Times," in Down from the Hill: Ateneo de Manila in the First Ten Years under Martial Law (Quezon City: Ateneo de Manila University Press, 2005), 211. See also Ramon Puno, "How 'Down from the Hill' Launched a Fruitful Dialogue on Filipinization," The Guidon, (11 December 1968).

${ }^{45}$ Alcuaz, et. al., "Down from the Hill," The Guidon, (27 November 1968). This article was published again in Cristina Jayme Montiel and Susan Evangelista, eds., Down from the Hill: Ateneo de Manila in the First Ten Years under Martial Law (Quezon City: Ateneo de Manila University Press, 2005).

(C) 2014 Franz Giuseppe F. Cortez http://www.kritike.org/journal/issue 14/cortez june2014.pdf ISSN 1908-7330 


\section{THOUGHTS OF ROQUE FERRIOLS}

Another important episode during the beginning years of Ferriols' teaching of philosophy in Filipino was the desire of many Filipino teachers of philosophy to search, discover and enrich what could be known as Filipino philosophy. This can still be linked to the general tendency of Filipino academics and intellectuals to problematize a Westernized culture and to promote nationalistic consciousness and sovereignty. In an article written by Romualdo E. Abulad, one of the pioneers of the discipline of philosophy in the Philippines, he calls this the indigenous phase in the history of Filipino Philosophy. ${ }^{46}$ The characteristic of this significant episode is best captured in these words from Abulad:

It all started when our philosophers became conscious of what they were doing and began to ask whether their work was contributing any to the nationalist cause. Weren't they simply mouthing foreign philosophies and artificially dumping them into the heads of our students? There developed among our academicians the qualms which arose from the suspicion that they had been reduced to willing albeit unwitting tools in the perpetuation of colonial ideas, all at the expense of the native genius. Hand in hand with this collective sense of guilt were the scruples brought about by the nagging feeling that all this time the Filipino intellectual had failed to live up to the requirements of original and originative thinking. ${ }^{47}$

Ferriols also shared his thoughts regarding the efforts on the search for Filipino philosophy. He says:

Madalas may nagtatanong: Mag-iimbento $k a$ ba $n g$ pilosopiyang Pilipino? O kaya: Maari bang magkaroon ng pilosopiyang Pilipino? Ang mga tanong na iyan ay pagaksaya ng panahon. Kung talagang nais ng isang taong mamilosopiya, ang hinahanap niya ay ang totoo na nagpapakita sa kanya. At gagamitin niya ang anomang makakatulong sa paghanap sa totoo. Kung ang pinagaabalahan niya'y Pilipino ba ako? o Intsik? o Indian? o kung ano? hindi na siya mamimilosopiya. Lalabas siyang gaya ng

${ }^{46}$ Abulad, "Contemporary Filipino Philosophy," in Karunungan 5 (1988), 5.

${ }^{47}$ Ibid., 5.

(c) 2014 Franz Giuseppe F. Cortez http://www.kritike.org/journal/issue 14/cortez june2014.pdf

ISSN 1908-7330

(cc) BY-NC 
taong tingin nang tingin sa salaming sa walang katapusang pagka-bagabag na baka hindi siya mukhang Pinoy." 48

In another instance, this is what Ferriols has to say:

Ngayon, mayroong nagtatanong sa akin, 'Mayroon bang pilosopiyang Pilipino?' Sabi ko na parang pagkaing Filipino ang pilosopiyang Pilipino. Filipino ako. Kung mayroon akong pagkain na nasasarapan ako, pagkaing Filipino iyon. Kung imbitahin mo akong kumain sa McDonald's, at masarapan ako sa pagkain doon, 'yung pagkain hindi ko kinakain sapagkat Amerikano ito. Kinakain ko kasi gusto ko. At kaya nga nagiging Filipino food kung ako ang kumakain. ${ }^{49}$

For Ferriols the issue of philosophy having a Filipino identity is not an issue at all. What is important is that the one who philosophizes is searching for the truth. Descartes, Hegel, Chuang Tzu and other famous philosophers did not preoccupy themselves with the issue of whether what they were doing is French or German or Chinese. They simply searched for the truth. ${ }^{50}$

To sum up, we can say that Ferriols' choice to philosophize and to teach philosophy in Filipino happened in the midst of the issues of Filipinization and nationalism, social unrest and student activism during the regime of Marcos, and the search for and development of Filipino philosophy.

\section{The Expressed Reasons of Ferriol's Linguistic Turn}

Before I discuss Ferriols' expressed reasons, I will talk first about his expressed non-reasons. First, as discussed above he said that he is not deliberately attempting to develop a Filipino philosophy. For him, a genuine philosophical thought is not deliberately created or developed. He mentions the experiences of the great philosophers.

No one can create a Filipino or anything else philosophy except by accident. Chuang Tzu did not try to develop a Chinese philosophy...What more German than Hegel or Nietzsche? Yet neither are in agonies to be Germanic...At the beginning of Discours de la method, Descartes says half proudly half apologetically that he is

\footnotetext{
${ }^{48}$ Ferriols, Pambungad sa Metapisika, 236.

${ }^{49}$ Ferriols, "An Interview with Ferriols," in University Traditions, 182-183.

${ }^{50}$ Ferriols, "A Memoir of Six Years," 216-217.
} 


\section{THOUGHTS OF ROQUE FERRIOLS}

writing in French. For the rest of the work he simply philosophizes...As a philosopher is, so he philosophizes. And in his philosophizing all the tension, combat, exoticness, rootedness of who he is begin to show their inner truth. ${ }^{51}$

Second, although he is concerned about various views on the issue of national language, Ferriols also said that his intention in using the native language to philosophize and to teach philosophy is not to help in the efforts to make Tagalog the national language. He says: "I have put in my time listening to and participating in endless debates on this topic. Until now, when I can, I try to provide a forum for interesting views on the matter. But life is short and debate is endless." 52 For Ferriols, what is of prime importance is not the debate and its political repercussions but rather the commitment to act on one's conviction. That is why, even if the debate was still ongoing and heated, he simply embarked on the journey of philosophizing and teaching philosophy in Filipino. As he said, it was already provided in the Philippine Constitution. ${ }^{53}$

But what could really be the expressed reasons why Ferriols was so passionate in using the native language as medium of philosophizing and of teaching philosophy? Fortunately for us, in the same essay where he clarified his non-reasons, Ferriols also articulated his concrete intentions. He discloses:

When I try to philosophize in Pilipino, it is with intent to live and to help awaken other people into living. Each language is a way of being alive that is irreducible. Yes, the things languages do, overlap and, if one just wants to do things with words, he can learn to reduce one manipulation to another. There are those who spend their lives producing vast linguistic networks of mutually reducible manipulations. But he who has touched the heart of a language, even if only for a split second, knows that it is an irreducible way of being alive. Each language has unrepeatable potentials for seeing and feeling, its very own genius, its own nuance. ${ }^{54}$

\footnotetext{
${ }^{51}$ Ferriols, “A Memoir of Six Years," 339.

52 Ibid., 340.

${ }^{53}$ Ibid., 338.

${ }^{54}$ Ibid., 340. http://www.kritike.org/journal/issue 14/cortez june2014.pdf
}

(c) 2014 Franz Giuseppe F. Cortez ISSN 1908-7330 
Here, we can see some of Ferriols' expressed reasons. First, he "intends to live and to help awaken other people into living." This suggests that for Ferriols, one may be biologically alive but does not really live authentically. As a teacher of philosophy, he is convinced of its potential to lead the students to reflect about authentic living and not just mere breathing. That is why from the outset, he makes it clear that the task of every teacher and student of philosophy is not just to define it at once. Rather, one has to do it. One understands and learns what philosophy is by doing philosophy, by the very act of philosophizing. ${ }^{55}$ Thus, Ferriols has become famous to his students for his analogy of the act of learning how to philosophize and the act of learning how to swim. One cannot learn how to swim just by listening to the swimming instructor (even if he is the best instructor in the whole world) or by reading all the books about swimming. He/she has to dive into the pool. ${ }^{56}$ One cannot learn philosophy by just listening to the teacher of philosophy. One has to philosophize. He/she has to dive not into the clear bathwater of a pool but into the muddy waters of philosophy.

However, it is not sufficient that one philosophizes in order to have a deeper understanding of what philosophy is. For Ferriols, there is another precondition-language. That is why Ferriols' second reason flows from a deep awareness that the very act of philosophizing is necessarily linked to the language being used by the person who philosophizes. The language that is spoken must be intimately linked with what one thinks and how he/she thinks. With Ferriols in mind, Rodriguez and Que explain: "If one were to teach living thought to students, they need to be made to speak in their living language. That is to say not the formal language of memorized formulas and petrified discourse, but the language with which they experience their world and live their reality. Thus, the necessity to allow philosophy to speak in Filipino." 57

The third reason why Ferriols uses Filipino in philosophizing and in teaching philosophy is that for him every language has its own uniqueness, nuances and abilities. Language is a "unique way of being alive that is irreducible." 58 There are some experiences that cannot be expressed fully using a foreign language. In a conference of Ateneo students, teachers and administrators a few days after the "Down from the Hill Manifesto" was published in November 1968, Ramon V. Puno reports about Ferriols being vocal in expressing his insights regarding the issue of language. Puno says that Ferriols "pointed out that there are some insights which are expressible

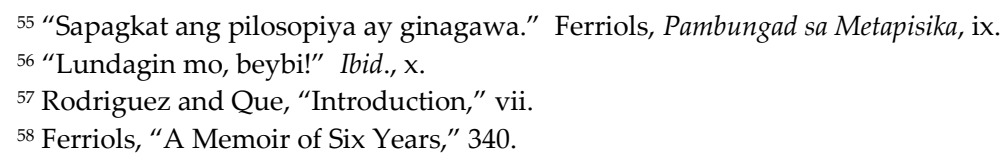




\section{THOUGHTS OF ROQUE FERRIOLS}

only in a certain language." 59 In fact, there are some words in a particular language whose meaning cannot be captured by merely translating the word into another language. ${ }^{60}$ In a discipline such as philosophy where a person who truly philosophizes has to become sensitive to his/her fundamental human experiences, language as the expression of those experiences also takes a fundamental role. It is on this line of thought that in the same essay, Ferriols would exclaim later his personal experience: "In six years one comes to know that, for human thinking, North Sampalokese is better than Plato's Greek." 61 And that is coming from a man who is known to be well-versed in so many languages including the Greek language. ${ }^{62}$

In a separate instance, Ferriols also explained the important role of language in the human person's search for the truth.

Bukal sa lahat ng tao ang hanapin ang katotohanan, at lahat ng wika ay likha ng tao. Kaya't taglay ng bawat wika ang kapaitan at pananabik ng paghabol sa katotohanan: paghabol na ginanap ng mga unang naghubog at ng mga sunod na gumamit sa wikang iyon. Kaya't lahat ng wika ay maaring gamitin sa paghanap sa totoo kung may kalooban ang gumagamit. At kung ayon sa totoo ang kanyang paggamit. ${ }^{63}$

Thus, the fourth reason for Ferriols' choice comes from an awareness that the human person as a natural truth-searcher has his/her own language that can be deployed in his/her unceasing search for the truth. It appears, therefore, that for Ferriols, in humanity's search for the truth, no language can be considered inferior to the other. The languages of the Greeks, the Germans, the French and the Americans cannot monopolize the human

${ }^{59}$ Puno, “How 'Down from the Hill' Launched a Fruitful Dialogue on Filipinization,"

3.

${ }^{60}$ Even Freire himself notes that the meaning of conscientizacao cannot be captured completely by its English translation of "conscientization." See Freire, The Politics of Education, 185.

${ }^{61}$ Ferriols thinks that what he is actually using is not the formal, technical and academic Filipino language. Rather, he is using a nuance of Filipino spoken by people like him who grew up in the northern part of Sampaloc, a barangay at the heart of Manila. Thus, he calls this North Sampalokese. See Ferriols, "A Memoir of Six Years," 344.

62 "Fr. Roque himself reads Latin, Classical Greek, French, and German. He speaks Ilocano, Tagalog, Cebuano, and English. He is himself an excellent prose stylist in English." Rodriguez and Que, "Introduction," vii. He is also known for translating some texts from the original Greek version to Filipino. See Geoffrey Guevara, "Si Ferriols sa Gilid," paper presented at the Mid-Year Conference of the Philosophical Association of the Philippines, De La Salle University, Manila, Philippines, October 18, 2012.

${ }^{63}$ Ferriols, Pambungad sa Metapisika, 236.

(c) 2014 Franz Giuseppe F. Cortez

http://www.kritike.org/journal/issue 14/cortez june2014.pdf

ISSN 1908-7330

(cc) BY-NC 
person's search and discovery of truth. Every language possesses a unique potential in the attempt to express significant human experiences.

Ferriols notes that there are people who insist that the language to be used in philosophizing is not that significant after all. What is important is that the person honestly searches for the truth and he/she can use any language he/she is most comfortable with and which he/she has mastered. The following is Ferriols' response to it:

\begin{abstract}
Madalas akong pagpunahan na kung katotohanan ang hinahanap mo, hindi importante kung anong wika ang gagamitin mo sa iyong pamimilosopiya. Iyan ay isang delikadong puna. Kung may tao sa aklatan, at sinusubukan niyang mamilosopiya sa isang wika na ibang di hamak sa sinasalita ng mga nagmamaneho ng dyipni, nagwawalistingting sa mga kalsada, nagsisilbi sa mga turo-turo, masasabi kaya na ang taong iyon ay gumagalaw sa katotohanan? Sapagkat hindi maipagkakaila na, angkinin man ng tao o sadyang limutin, palaging mananatiling totoo na lahat ng tao, pati ang mga namimilosopiya, ay napapaligiran ng mga kapuwa tao na nagsasalita. At kapag ang nagsisikap mamilosopiya ay pumipili sa wikang gagamitin niya, ang kanyang pagpili ay bunga ng kanyang atitud sa salita ng mga pumapaligid sa kanya. At ang kanyang atitud ay maaring katotohanan, maaring kasinungalingan. ${ }^{64}$
\end{abstract}

From this explanation, one can gather a fifth important reason why Ferriols uses the native language in philosophizing and in teaching philosophy. For him, the person who philosophizes and searches for the truth must also immerse himself/herself into the lives of ordinary people. The person who philosophizes does not reside in an ivory tower that is totally isolated from the affairs of ordinary people. The philosopher lives in the midst of people who use and speak a particular language as they communicate with each other. The person who philosophizes, if he/she is faithful to his/her search for the truth, reverently and humbly bites into what is concrete and lived.

\title{
The Political Aspect of Ferriol's Linguistic Turn
}

Ferriols is also a teacher, and a teacher of philosophy at that. Even if his main philosophical project is different from the concern of Freire in

${ }^{64} \mathrm{Ibid} ., 236$.

(C) 2014 Franz Giuseppe F. Cortez

http://www.kritike.org/journal/issue 14/cortez june2014.pdf

ISSN 1908-7330 
particular and critical theory in general, his choice of the language of philosophizing and the teaching of philosophy and the accompanying thoughts on this choice cannot be utterly separated from the concerns of the critical pedagogues and dismissed outright as completely devoid of any politics. In spite of his outright denial of political participation, by choosing Filipino as his language of philosophizing and teaching philosophy, Ferriols is involved in a certain form of politics. Thus, it opens itself to the concerns of critical educators such as Freire. I argue that Ferriols' linguistic turn manifests a kind of politics in the Freirean sense.

We start from the fundamental premise held by various intellectuals that language and politics are intimately intertwined. For example, the American linguist, philosopher and political critic Noam Chomsky famously declares without any hesitation that "[q]uestions of language are basically questions of power." 65 This categorical statement is better understood in reference to what Chomsky is saying a few paragraphs above the said statement in the book Language and Responsibility. Chomsky asks:

What is the 'Chinese language'? Why is 'Chinese' called a language and the Romance languages, languages? The reasons are political, not linguistic. On purely linguistic grounds, there would be no reason to say that Cantonese and Mandarin are dialects of one language while Italian and French a single language?...So what is a language? There is a standard joke that a language is a dialect with an army and a navy. These are not linguistic concepts. ${ }^{66}$

Chomsky is sure that the issue of the difference between language and dialect is not after all a linguistic issue. Rather, he sees it as a political one, that is, as an issue of power relationship between a language that dominates and a language that is being dominated. Later on, those who are interested in the thoughts of Ferriols may be surprised to find out that Ferriols himself has this kind of awareness when he made a very short and casual but, for me, a significant comment concerning the issue of language over and above a dialect.

In his book about minority languages, Stephen May, an expert in language and multicultural education touches on the phenomenon of

${ }^{65}$ Noam Chomsky, Language and Responsibility, trans. by John Viertel (NY: Pantheon, 1977), 191.

${ }^{66}$ Ibid., 190.

(c) 2014 Franz Giuseppe F. Cortez

http://www.kritike.org/journal/issue 14/cortez june2014.pdf

ISSN 1908-7330

(cc) $\mathrm{BY}-\mathrm{NC}$ 
language loss. ${ }^{67}$ May observes that the said phenomenon is oftentimes the result of unequal distribution of power and blatant acts of discrimination and subordination. ${ }^{68}$ On the other hand, the British sociolinguistics scholar John Earl Joseph also emphasizes the politics involved in the choice of language especially among non-monolingual societies, or those societies that have more than one language. He says that there is always politics involved in the choice of language to be used in a non-monolingual society. It is because the choice of one language over and above another is always accompanied by some sort of sanction. ${ }^{69}$

The Philippine linguistic scenario is undoubtedly included in the non-monolingual societies that Joseph is describing. And then as discussed above, Ferriols was not immune from a form of sanction resulting from his choice.70 For this reason, Rodriguez and Que report of Ferriols' "years of struggling with prejudice" 71 and "the great resistance from the administration," 72 while the young Alcuaz complained about the plan to eradicate Ferriols' infant philosophy class in Filipino because of lack of enrollees while other subjects with few enrollees are not affected by this planned sanction. ${ }^{73}$ Considering this, Joseph is justified in concluding that "in postcolonial contexts, the choice between the former colonial or imperial language and an 'indigenous' language is almost always politically charged, though in different ways in different places." 74

Likewise, Freire himself holds the conviction that "it is not possible to discuss language without discussing power or without thinking about social classes and their contradictions." 75 Then, he declares again in another later book that "the problems of language always involved ideological questions and along with them, questions of power."76 Furthermore, in an article written by Renato Constantino, a famous Filipino nationalist historian, he says that any project that endorses the promotion of the use of the native language as medium of instruction participates in the over-all project of nationalism and emancipatory education. Constantino says: "Fortunately,

\footnotetext{
67 "Language loss refers to the suppression of an indigenous language or mother tongue." "Language Loss," in Sage Knowledge. Date Accessed: 16 March 2013, $<$ http://knowledge.sagepub.com/view/identity/n147.xml>.

68 Stephen May, Language and Minority Rights: Ethnicity, Nationalism and the Politics of Language (NY: Routledge, 2012), 4.

${ }^{69}$ John Joseph, Language and Politics (Edinburgh: Edinburgh University Press, 2006),

10.

${ }^{70}$ Ferriols, "A Memoir of Six Years," 338-339.

${ }^{71}$ Rodriguez and Que, "Introduction," v.

${ }^{72}$ Ibid., vii.

73 Alcuaz, "Students Robbed of Moral Victory," 3.

${ }^{74}$ Joseph, Language and Politics, 10.

${ }^{75}$ Paulo Freire, Pedagogy of the City (New York: Continuum), 133.

${ }^{76}$ Freire, Teachers as Cultural Workers, 74.
} 


\section{THOUGHTS OF ROQUE FERRIOLS}

educating for ignorance is not the only trend that exists. There is a countertrend informed by nationalism and a sense of commitment to people's interests. This countertrend is seen in the efforts for the development and use of the national language as medium of instruction..."77

The point of all these insights from different thinkers is to demonstrate that the issue of language, especially as an issue for the medium of instruction, cannot be detached from the question of power and politics. Thus, when Ferriols chose his medium of instruction for philosophizing and for teaching philosophy, he cannot help but enter also the realm of the politics of language and the larger issue of the politics of education.

This point is further bolstered by the basic premise in Freire's liberating pedagogy discussed above: the non-neutrality of any educational process. Freire claims that education always has a political character. In fact, he would even modify this claim by saying that education not only has a political character. Rather, education is always political. ${ }^{78}$ And the teacher is always a politician. ${ }^{79}$ The teacher always carries consciously or unconsciously a particular politics. He/she advances specific views, interests and goals. His/her classroom is either a site for domination of some kind or for liberation of another kind. The different instrumentalities of education reflect also the interests of those who facilitate the classroom and administer the school. And the medium of instruction is certainly one of the crucial instrumentalities in any pedagogical process.

Thus, in this line of thinking, we can also say that Ferriols enters the realm of politics of education that Freire is describing even if Ferriols makes a straight-away denial of his involvement with politics. In fact, what one can notice in this outright denial is his non-approval of that aspect of Filipinization movement that, as the authors of "Down from the Hill" believe, is concerned with the "radical restructuring of the present social, political and economic order to make a just society." 80 Given the fact and as discussed also earlier that Ferriols' choice coincided with the era of the rise of Marxist and Maoist ideology, probably in the mind of Ferriols, a call for radical restructuring is also a dangerous invitation for the institution of a Philippine society under a brand of communism that is also at the same time a form of totalitarianism and authoritarianism. And in one of his articles, Ferriols makes it clear that in a totalitarian state, human freedom is compromised.

\footnotetext{
77 Constantino, "Educated Ignorance," in Fetters on Tomorrow, ed. by Lourdes Balderrama-Constantino (Quezon City: Karrel Inc., 1996), 88.

${ }^{78}$ Freire and Shor, A Pedagogy for Liberation, 61.

${ }^{79}$ Ibid., 46.

${ }^{80}$ Leonardo Montemayor, "Our Westernized View of Filipino Nationalism," in The Guidon, (January 30, 1969), 2.

(c) 2014 Franz Giuseppe F. Cortez http://www.kritike.org/journal/issue 14/cortez june2014.pdf ISSN 1908-7330
} 
Thus, total human flourishing can never be achieved. ${ }^{81}$ Ferriols cannot join the groups affiliated with totalitarian tendencies. In other words, he is not in favor of a communist take-over. That is why in a recent published interview, Reyes is justified in claiming that Ferriols kept quiet when radical Ateneans started using and quoting Ferriols. Reyes narrates:

Fr. Ferriols had a very strong influence in [the Filipinization movement]. Then at a certain point, the activist students were riding on this. Fr. Roque, to my perception, realized that these activists were out to destroy the school, and at that point, I noticed he kind of quieted down. The activists were confusing the issues; they wanted to bring down the school. Of course, Fr. Roque's fight was something else. ${ }^{82}$

Similarly, Benjamin Tolosa, Jr., a teacher of Development Studies at the Ateneo, describes the Filipinization process where Ferriols was seriously involved as a politics "above the ground and not overtly political in character." 83 Covert or overt, it is still politics.

If Ferriols' choice is also a political one (consciously or unconsciously), the next relevant question is: For whose interest and against whose interest is Ferriols' linguistic turn? Garcia's statement provides a plausible answer to this question.

The main role [of philosophy] was to articulate our being Filipino and to articulate it in the language of Pilipino [now Filipino]. I think that ' 68 was the time when we embarked on Filipinization through the efforts of Fr. Ferriols, a Magpakatao-ist...It was markedly antiAmerican, pro-Filipino. It was the anti-American that was more evident. ${ }^{84}$

And then, in the interview that Tolosa was referring to, Ferriols was asked whether there is a need to revamp and restructure the administrative set-up of the Ateneo. He replies:

\footnotetext{
${ }^{81}$ Ferriols, Pagdiriwang sa Meron, 297-298.

82 Reyes, "An Interview with Ramon Reyes," in University Traditions, 236.

83 Benjamin Tolosa, "From Social Involvement to Nonviolent Political Struggle," in Down from the Hill, 256.

${ }^{84}$ Garcia, "An Interview with Dr. Garcia," in University Traditions, 213. 


\section{THOUGHTS OF ROQUE FERRIOLS}

If you mean the way the structure is being used, I think it should be reoriented in the direction of more cultural realism because the present set-up is being used to perpetuate a cultural island on Philippine soil. By this I mean that the frames of reference within which the Ateneo operates are to a great extent bodily transplants from the United States. Even the way English is used is full of American meanings. It is very hard to express what one really wants to express. And in a discussion with American Jesuits, they have the advantage because they are using their own language, and they can always in all kinds of subtle ways misunderstand-whether deliberately or indeliberately I do not know - what a Filipino using English really wants to say. ${ }^{85}$

Here, Ferriols is calling our attention to see that the systems of knowledge that are promoted inside the Ateneo education (and in Philippine education in general) are perspectives molded in the American soil while being conveyed in the American language. The result of this is the creation and rise of a "cultural island on Philippine soil."

Thus, Ferriols' choice of Filipino as the language of philosophy and the medium of instruction can also be read as his small contribution in an ongoing process of decolonization rooted in nationalist discourse. Garcia is justified in calling it as "markedly anti-American and pro-Filipino" where the anti-American is more evident. ${ }^{86}$

But it seems that Ferriols is not only operating in the realm of an unconscious or accidental politics that Freire is suggesting when he says that the teacher may knowingly or unknowingly be an agent of domesticating education or of a liberating one. ${ }^{87}$ Some interspersed texts from Ferriols further reveal that he also sees that language itself is a field of power struggle between a culture that dominates and a culture that is dominated. Hence, he is consciously or deliberately problematizing it. In his 1975 article reflecting on his first six years of teaching philosophy in Filipino, Ferriols responds to the question "How do you translate philosophical terms?" He explains:

That is really no problem. Most English philosophical terms are really Latin words (subjectivum, objectivum,

\footnotetext{
${ }^{85}$ Roque Ferriols, "A Call for Cultural Realism," an interview by Ramon V. Puno and Vicente A Cabanero, The Guidon, (December 11, 1968), 3.

${ }^{86}$ Garcia, "An Interview with Dr. Garcia," in University Traditions, 213.

${ }^{87}$ Freire, Pedagogy of the Oppressed, trans. by Robert R. Barr (New York: Continuum, 1995), 61. See also Freire, The Politics of Education, 179.

(c) 2014 Franz Giuseppe F. Cortez http://www.kritike.org/journal/issue 14/cortez june2014.pdf ISSN 1908-7330
} 
intuitio, praedicatum) somewhat mispronounced and misspelled (subjective, objective, intuition, predicate). Or Greek words similarly distorted (metaphysics). The Germans sometimes use Latin and Greek (subjektiv, Metaphysik) or create their own terms (Mitzumachung) or do both at the same time (Objekt, Gegenstand). We followed the German model. ${ }^{88}$

On this reply, Ferriols drives the point that it is just normal for many languages like German and English to borrow Latin and Greek terms. Thus, it should not be taken as a big deal if the Filipino language also borrows foreign terms..$^{89}$

But then again, Ferriols sees something else. For him the question "How do you translate philosophical terms?" is a question that is loaded with a more serious presupposition that may have deeper repercussions. He explains further:

But this question was not usually asked as a request for suggestions on how to proceed or for information on how we proceeded. Usually, it was asked rhetorically, as a way of saying: You cannot do this. Sometimes so bitterly as to mean: You cannot do this to me. Often the question was a cover for a presupposition that what English and Spanish are allowed to do cannot be allowed to Tagalog or any Filipino language. So intuition is 'derived from' the Latin. Coffee and alcohol are 'derived from' the Arabic. But sumbalilong is a 'corruption of' the Spanish, istrok 'corrupted from' the English..$^{90}$

At this point, Ferriols turns to a very important issue in the seemingly innocent question, "How do you translate philosophical terms?" He calls this a rhetorical manner of asking question. But if one would follow the discourse of Freire's liberating pedagogy, what Ferriols is trying to say is that it is a question that is colored with a particular politics. It is what Joe Kincheloe, a North American critical pedagogue, refers to as "questioning the hidden

${ }^{88}$ Ferriols, "A Memoir of Six Years," 342.

${ }^{89}$ Ferriols does not like the idea of "borrowing." As early as 1969, his students are already aware that Ferriols is already particular with this term "borrowing." Montes says: "In fact, Father Ferriols does not want to call this borrowing; he prefers to say 'Magnanakaw tayo' ('We will steal'), because according to him, great men do not borrow, they steal." Montes, "Pilipino Philosophy Course," 2.

${ }^{90}$ Ferriols, "A Memoir of Six Years," 342.

(C) 2014 Franz Giuseppe F. Cortez http://www.kritike.org/journal/issue 14/cortez june2014.pdf

ISSN 1908-7330 


\section{6}

THOUGHTS OF ROQUE FERRIOLS

political assumptions"91 of language in this case. It is a question that insinuates that a particular language is more superior to another one. It is a question that presupposes that the language of the dominated has no capacity and/or right to translate the language of the dominator. What Ferriols sees as embedded in the question "How do you translate philosophical terms?" is a perception and attitude that the Philippine languages are backward and cannot carry the weight of the meaning of the language of the dominator. Ferriols continues his critical observation of the question.

Another form this question took was: How do you say 'being' in Pilipino? Asked with a facial aha-this-showsyou-cannot-do-philosophy-in-Pilipino expression...The question proceeds from the hidden conviction of the asker that nothing profound has happened in any Filipino language, that translations of foreign terms are not mere ornaments of helps but the very life blood of Filipino thought. ${ }^{92}$

Here, Ferriols is involved in a critique of a dominated or colonized consciousness. He attempts to expose the naivete of the dominated consciousness. He shows that for this kind of consciousness, his/her own language is ill-equipped to carry the burden and complication of the act of philosophizing, which foreign language like English can do. Ferriols further exposes that for this dominated consciousness, "nothing profound has happened in any Filipino language" and that "translations of foreign terms... are the very lifeblood of Filipino thought." In other words, Ferriols brings into the open a form of naivete brought about by a long process of invasion in and through language-that the Filipino language and the Filipino thought are inferior to the language and thought of the colonizer. Certainly, this is a political insight, one that problematizes the dominant language and defends the dominated language. Freire himself says:

The colonizers spent centuries trying to impose their language. The colonized people were told either verbally or through message systems inherent in the colonial structure that they did not possess effective cultural instruments with which to express themselves. This language profile imposed by the colonizers eventually convinced the people that their language was

${ }^{91}$ Kincheloe, Critical Pedagogy Primer, 34.

${ }_{92}$ Ferriols, "A Memoir of Six Years," 342.

(c) 2014 Franz Giuseppe F. Cortez

http://www.kritike.org/journal/issue 14/cortez june2014.pdf

ISSN 1908-7330

(cc) BY-NC 
in fact a corrupt and inferior system unworthy of true educational status. ${ }^{93}$

That is why we can really say that Ferriols is breaking a particular politics: the politics of linguistic colonialism. And because it is a specific politics that he is trying to break, what he is doing is also a political act.

In his interview with The Guidon two weeks after the publication of "Down from the Hill," Ferriols further shows his sensitivity to the politics involved in language. In a seemingly innocent comment, he demonstrates his awareness of the power play behind the distinction between "dialect" and "language." He says: "In spite of centuries of colonization, we have been able to preserve our languages. By languages I mean what are sometimes called with condescension, dialects." ${ }^{94}$ If seen from the discourse of the critical pedagogues, this statement is a political one. Ferriols prefers to use the term "language" rather than the term "dialect" given or constructed by the colonizer and/or the colonized intellectual.

This insight can be best understood if seen from the perspective of linguistic politics. As mentioned earlier, Chomsky is convinced that the differentiation between language and dialect made especially by those who dominate is not after all a linguistic issue. Rather, it is a political one. To further bolster this claim, in his book Linguistic Imperialism, Robert Phillipson also discusses the racist ideology behind such differentiations. Phillipson observes that the labels tribe and dialect are expressive of the myth of colonialist culture. These labels manifest how the dominator differentiates itself condescendingly from the dominated. Thus, it is a manifestation of racist ideology. "The rule is that we are a nation with a language whereas they are tribes with dialects." 95 Phillipson further accentuates his point by mentioning the 1974 work of the French linguistics professor Jean-Louis Calvet. Phillipson explains that for Calvet, one of the serious failures of traditional linguistics is the neglect in seeing the issue of power embedded in the distinction between dialect and language. "For [Calvet] 'a dialect is never anything other than a defeated language, and a language is a dialect which has succeeded politically'." 96 Thus, when Ferriols comments on the "condescension" accompanying the term "dialect," what he does actually is enter the politics involved in language and problematize what Amy Tsui and

\footnotetext{
${ }_{93}$ Freire and Macedo, Literacy: Reading the Word \& the World, 118.

${ }^{94}$ Ferriols, "A Call for Cultural Realism," 3.

${ }^{95}$ Robert Phillipson, Linguistic Imperialism (Oxford: Oxford University Press, 1992), 38.

${ }^{96}$ Ibid., 39.
} 


\section{THOUGHTS OF ROQUE FERRIOLS}

James Tollefson call "the asymmetrical power relationship between languages." ${ }^{97}$

Ferriols is also consciously problematizing elitism in education -a common feature of the Ateneo education during that time. Ferriols calls into question an elitist mentality manifested in an elitist language - a belief that speaking in English is the mark of good education and sophistication. Roberto Javier, another one of his first students, writes about the common perception of many students in the Ateneo during that time: "Ewan ko nga ba. Pero pag hindi ka naman Ingles nang Ingles e dehins ka na class, pare. Sayang lang ang ibinabayad mo sa Ateneo...Para yata sa atin kailangan maging foreign bago maging class ang isang bagay." 98 Edgar Jopson, a student activist and one who is closer to the era when Ferriols made his choice, describes the Ateneo in these words: "Ang Ateneo na lagian na lamang itinuturing ng mga karamihan na luklukan ng wikang banyaga, kuta ng mga Pilipinong nagtatangusan ng ilong sa pagpipitpit ng kanilang dila sa bantog na Ateneo accent." 99 Then, many years after, Rodriguez and Que would recall Ferriols standing and teaching in front of "properly dressed, properly Englished, properly aristocratic Ateneans."100 An editor's note on The Guidon reveals further a feature of this elitism, a snobbish attitude towards the native language. It says:

The [Guidon] staff had been planning to release a [Filipino issue of Guidon] for some time now; despite its feasibility, doubts were raised as to student reaction about it. The previous Pilipino pages, it was discovered, were hardly ever read by anyone; it was discouraging to say the least. Some argued that as things stood, the Pilipino page was only taking space which could be used more profitably with articles that would be read and was only adding an unnecessary financial burden. ${ }^{101}$

Ferriols is also out to challenge this elitism. In an informal article written by Roberto Javier, he reveals Ferriols' propensity to use vulgar words. Javier narrates how the whole class would break into boisterous laughter and shouting as the Jesuit priest repeatedly utters the Tagalog words for phallic

97 Amy Tsui and J. Tollefson, "The Centrality of Medium-of-Instruction Policy in Sociopolitical Processes," in Medium of Instruction Policies: Which Agenda? Whose Agenda? (New Jersey: Lawrence Earlbaum Associates, 2004), 14.

${ }_{98}$ Roberto Javier, “Ututang Dila, Nagmamantika," in The Guidon, (August 21, 1969).

${ }^{99}$ Edgar Jopson, "Talumpati't Pagpupugay," in The Guidon, (August 21, 1969).

100 Rodriguez and Que, "Introduction," v.

${ }^{101}$ Editor's Note in Tiglao, "The Guidon Should use Pilipino," 3.

(c) 2014 Franz Giuseppe F. Cortez

http://www.kritike.org/journal/issue 14/cortez june2014.pdf

ISSN 1908-7330

(cc) BY-NC 
symbols when they talked about primitive religions and fertility rites. ${ }^{102}$ Then, Javier says that Ferriols would tell his students: "Kayo kasi. NapakaForbes-Parkish ang inyong mentality. Sa mga Tundo at ibang sulok diyan e balewala yan. Yan ang problema sa Ateneo education. Masyado kayong nagiging puritanical. Nawawala ang pagkadown-to-earth na inherent sa inyong tunay na wika." 103 Ferriols' vulgarity has endured as subsequent students of the respected and respectable Catholic Jesuit priest Roque Ferriols would narrate about his tendency to explode into "fireworks of expletives." 104 And this cannot be explained simply in terms of rudeness of character or enslavement to an uncontrollable habit or mechanical expression of a sudden burst of emotion. Rather, Calano explains that the famous verbal invectives is "pedagogical, Fr. Ferriols wants to convey a message."105

Ferriols' concern for elitism brought about by the Atenean education becomes more manifest in his comment about the creation of "a cultural island" inside the Ateneo. ${ }^{106}$ The Atenean education becomes an island in itself detached and isolated from the Philippine reality. The school and its students are quarantined from the diseases of the wider Philippine society. And as it happens, the Ateneans are also thrown into social irrelevance. The notion of a cultural island created partially but significantly through the English language and culture proliferating in the Ateneo is both a problematization of the colonial character of English and its potential to further elitize the Ateneans.

But there is another side to the Atenean student. In an interview with Dante Simbulan, a teacher of political science and history in the Ateneo, he has this to describe the typical Atenean of those days:

The Atenean as a student has that normal desire to acquire knowledge of things which he considers as relevant to his environment. He too seeks to correct the evils of society which he sees. However, the Atenean has unconsciously absorbed certain attitudes, values, and a frame of mind which are part of the social milieu in which he lives. His being in the upper strata of society, his elite position contributes to the shaping of his standards according to the accepted norms of his strata.

\footnotetext{
102 Javier, “Ututang Dila, Nagmamantika," 4.

${ }^{103}$ Quoted in Ibid., 4.

104 Rolando Tinio, "What are Ferriols," in Pagdiriwang sa Meron, 12.

105 “Nagmumura iyan sa loob ng klase...Ke Roque, ang kanyang pagmumura ay laging pedagohikal. Laging meron siyang gustong ituro." Mark Calano. Interview with Cortez, March 20, 2013.

${ }^{106}$ Ferriols, "A Call for Cultural Realism," 3.
}

(C) 2014 Franz Giuseppe F. Cortez http://www.kritike.org/journal/issue 14/cortez june2014.pdf ISSN 1908-7330 
This is not something deliberate. The Atenean's failure to grasp the reality of the situation is due to his very status, to his 'vantage of view.' His social class forces him to adopt certain modes of thinking or abstractions which are often unfaithful to reality. Ateneans, especially the concerned and socially-involved student leaders, should try to extricate themselves from their vantage point of view and seek to develop a genuine merging of interests with the people. So long as they attempt to study the situation from their vantage point of view, so long will they continue coming out with elitist 'solutions' which do not produce any real change in the systems. ${ }^{107}$

Taking this positive potential into context, the problematization of an elitist mentality by and through the use of the native language for philosophizing and teaching philosophy is not done just for the sake of problematization. Ferriols' politics of language moves further outward. He is thinking of what the Ateneo students can contribute in the larger Philippine society. Ferriols says: "The American Jesuits, through no fault of their own...are training Ateneans to work for the Philippines within a certain sector of society, instead of developing Ateneans who could work with all of the other sectors of Philippine society." 108

The problematization of elite education and elite language is done in order to go down from the hill and meet the ordinary people outside. It is on this line of thinking that one can also understand Ferriols' comments about Fr. Joseph Mulry, an American Jesuit priest residing in the Philippines, passionate in his campaign for justice, but not being understood by his target audience, that is, those who are the very victims of injustices. "[Ferriols] decried the fact that Fr. Mulry of pre-war fame was never understood when he spoke on 'social justice' in English." 109 Instead of creating a cultural island, Ferriols is sympathetic to the call for the Ateneans to "go down from the hill" or probably pushing the Ateneo island to merge itself with the rest of the Philippine landmass. And what could be more political than this?

With a striking similarity with Freirean pedagogy, Ferriols reminds the Ateneans by saying:

\footnotetext{
107 Dante Simbulan, "A United Front for National Democracy," an interview by Rigoberto Tiglao, in The Guidon, (February 17, 1970).

108 Puno, “How 'Down from the Hill' Launched a Fruitful Dialogue on Filipinization,"

3.

${ }^{109} \mathrm{Ibid} ., 3$.

(c) 2014 Franz Giuseppe F. Cortez

http://www.kritike.org/journal/issue 14/cortez june2014.pdf

ISSN 1908-7330
}

$(\mathrm{cc}) \mathrm{BY}-\mathrm{NC}$ 
The Atenean has to begin from the bottom...Go to the barrios and the poor sections of the city and make friends with the people. We like to make plans for the poor. We forget that to make an effective plan, we should be only one of the makers of the plan. We should cooperate with other people. This means to know them as human beings, appreciate them as human beings, to such an extent that we learn from them, and together with them we plan and execute. ${ }^{110}$

And how can the Atenean begin from the bottom if his/her language is totally alienating? How can he/she befriend the people if he/she is totally mesmerized and captured by elitist mentality and attitude? Thus, the purpose of Ferriols' linguistic turn is both a problematization of elitist mentality and an invitation to immerse with the concerns of the people from below. This immersion with the people from below, an act beginning from the bottom, is simultaneously a courageous act for the Ateneans to face the criticisms coming from the grassroots addressed to those who are at the top; in other words, indictment addressed to the Ateneans themselves.

As an important afterthought, let it be said further that this exploration is not meant to completely deny the value of the English language. Certainly, Ferriols is not a linguistic purist. ${ }^{111}$ Neither does he exclude the use of English or any other languages, an insight that is already emphasized by some Filipino scholars and former students who have engaged with the thought of Ferriols. Jboy Gonzales, a Jesuit priest and a former student of Ferriols has this to say:

Wika ni P. Roque sa amin: kung masasalita mo sa Bisaya ang itinuro niyang Pilosopiya, gamitin mo ang Bisaya. Kung Bikolano, gamitin mo ang wika sa pagsusulit. Sa mga misa niya, Ingles ang ginagamit niya. Ngunit may prinsipiyo: kung Ingles, Ingles ang buong pangungusap. Kung Pilipino, Filipino lahat. Walang Taglish, Bislish, Ilokanolish at iba pang lish-lish. ${ }^{112}$

${ }^{110}$ Ferriols, “A Call for Cultural Realism," 3.

111 Purism is "a pejorative term in linguistics for a zealous conservatism in regard to the use and development of a language." Richard Nordquist, "Purism." Date Accessed: 15 March 2013, <http://grammar.about.com/od/pq/g/purismterm.htm>. For a thorough discussion of linguistic purism, see also E. Annamalai, "The Linguistic and Social Dimensions of Purism," in The Politics of Language Purism (Berlin: Walter de Gruyter, 1989).

112 Jboy Gonzales, "Ang Wika ay Pagkakaibigan," in Faith of a Centurion: Homilies for Believers Willing to Take Risks, (August 10, 2009). Date Accessed: 15 March 2013, $<$ http://faithofacenturion.blogspot.com/2009/08/ang-wika-ay-pagkakaibigan.html>. 


\title{
72 THOUGHTS OF ROQUE FERRIOLS
}

\author{
Calano expresses a similar point.
}

Dapat maging malinaw na para kay Fr. Roque hindi naman nangangahulugan na Pilipino o wikang Tagalog lamang ang ating gagamitin sa ating pag-iisip. Para sa kanya, kung ikaw ay Cebuano gumamit ka ng Cebuano, kung ikaw ay Ilokano gumamit kang Ilokano, kung ikaw ay Bikolano gumamit ka ng Bikolano...Ang mahalaga lamang sa kanya ay wikang pagsasalubungan. Ibig sabihin na nakapag-uusap tayo sa wikang iyon at nagkakaunawaan. ${ }^{113}$

His project is not English-bashing, ${ }^{114}$ but as Rodriguez and Que said: "to speak their deepest experiences as human beings in their native tongue, be that Cebuano, Ilocano, Hiligaynon, or Waray." 115

But neither is Freire that naïve to deny the value of the colonizer's language. In fact, he would receive harsh criticisms for his pragmatic position on the use of the colonizer's language. ${ }^{116}$ Freire emphasizes the importance for the students to master the dominant knowledge in order to dominate it later on. "The dominant curriculum must gradually become dominated by the dependent students so as to help them in their struggle for social equity and justice." 117 To explain further Freire's position, the Freirean commentator Antonia Darder has this to say:

Paulo Freire always insisted that it is a political imperative for critical educators to develop a strong command of their particular academic discipline, whether that be within preschool or primary education, the middle or high-school grades, or higher education. By so doing, they can competently teach the 'official transcript' of their field, while simultaneously creating the opportunities for students to engage critically in classroom content from the standpoint of their own

\footnotetext{
${ }^{113}$ Calano, Interview with Cortez, March 20, 2013.

${ }^{114}$ It was not born out of hate for the Americans or the English language. See Ramon Reyes, "An Interview with Dr. Reyes," in University Traditions, 235.

115 Rodriguez and Que, "Introduction," v.

116 "But although Freire recognized and respected the value of subordinate students' primary culture and language, he did not believe that teaching children from oppressed communities solely in their primary language was sufficient - a belief for which he was much criticized and maligned." Antonia Darder, Reinventing Paulo Freire: A Pedagogy of Love (Colorado: Westview, 2002), 130.

${ }^{117}$ Freire and Macedo, Literacy: Reading the Word \& the World, 128.
}

(c) 2014 Franz Giuseppe F. Cortez http://www.kritike.org/journal/issue 14/cortez june2014.pdf ISSN 1908-7330 
knowledge and the events and experiences that comprise their living history. ${ }^{118}$

Then, as the postcolonial theorist Bill Ashcroft says regarding the capacity of the colonized to appropriate the colonizer's language, this process can be seized as an opportunity for self-empowerment. Ashcroft says:

Proficiency in the [colonizer's] language does not exclude the capacity to use it in a way that 'localizes' it...Mastering the master's language has been a key strategy of self-empowerment in all post-colonial societies...Cultural capital always presents itself as dominant: the 'proper', 'correct', 'civilized', way to behave. But this very dominance means that its appropriation by the colonial subject can be empowering. ${ }^{119}$

\section{Concluding Thoughts}

To conclude this paper, we can say that it is utterly myopic if Ferriols' choice is seen from a perspective devoid of any politics and is just overflowing with plain metaphysical ruminations. We cannot deploy the full potential of Ferriols who chose to philosophize and teach philosophy in Filipino if we limit it to apolitical interpretations. But if he is read and approached from the lens of Freirean liberating pedagogy, then it becomes more useful and more faithful to language itself which is always political especially when understood as an instrumentality of education which is also always political.

Ferriols cannot escape the politics of education understood in the Freirean sense. In fact, he was not escaping it. Even if he does not have a sustained analysis of the politics of language, there are interspersed texts showing that he is deliberately and consciously involved in the process of critique and problematization of colonial discourse and elitist mentality. And when he is alternatively seen as a participant in a wider discourse of linguistic politics, the readers of Ferriols become more aware of the liberating motive and potential behind his choice of Filipino for philosophizing and for teaching philosophy.

\footnotetext{
${ }^{118}$ Darder, Baltodano, and Torres, "Critical Pedagogy: An Introduction," in The Critical Pedagogy Reader, ed. by Antonia Darder, Marta Baltodano and Rodolfo Torres (NY: Routledge, c2009), 20.

${ }^{119}$ Bill Ashcroft, Post-Colonial Transformation (London: Routledge, 2001), 57-58.
} 


\section{THOUGHTS OF ROQUE FERRIOLS}

Joe Kincheloe describes that there are teachers that have impassioned spirit. By this, he means that these teachers are "dedicated and wellinformed...bringing a group of students to life with [their] knowledge, passion for learning and [their] ability to engage them in the process of teaching themselves and others." 120 It is not difficult to see Ferriols as a teacher with an impassioned spirit as described by Kincheloe, one who is committed to what he discovered, ${ }^{121}$ one who fought for what he was convinced of. Kincheloe adds: "Indeed, the impassioned spirit is never neutral."122 Indeed, Ferriols is never neutral. It is fortunate for us that his non-neutral stance regarding language is one big contribution in our unceasing search for understanding the Filipino mind, appreciating the Filipino culture, promoting Filipino nationalism, and constructing a bridge where the oppressor can start to dialogue with the oppressed with the former listening sincerely and humbly to the criticisms hurled at them by the latter.

Department of Philosophy, University of Santo Tomas, Philippines

\section{References}

Abulad, Romualdo, "Contemporary Filipino Philosophy," in Karunungan 5 (1988), 1-13.

Alcuaz, Jose et. al., "Down from the Hill," in The Guidon, (27 November 1968).

Alcuaz, Jose, "Students Robbed of Moral Victory," in The Guidon, (24 November 1969).

Annamalai, E., "The Linguistic and Social Dimensions of Purism," in The Politics of Language Purism, ed. by Bjorn H. Jernudd and Michael J. Shapiro (Berlin: Walter de Gruyter, 1989).

Ashcroft, Bill, Post-Colonial Transformation (London: Routledge, 2001).

Bernas, Joaquin, "A View from the Hill at 145." Date Accessed: 5 November 2012, <http://www.admu.edu.ph/index.php?p=502>.

Cabrera, Clodualdo, "The Pedagogical Role of English in the Reproduction of Labor," in Mula Tore Patungong Palengke: Neoliberal Education in the

\footnotetext{
${ }^{120}$ Kincheloe, Critical Pedagogy Primer, 4.

121 “Kapag iniisip ko ang konsepto ng 'dangal ng tao,' 'katarungan,' 'pagsisikap,'pagmamasid sa isip lamang ang nagaganap. Walang makapagsasabi na mali ako, o duwag, o kapuri-puri. Ngunit, kapag ako'y dumanas, nagmasid, kumilatis, - at sa pagmamasid at pagkilatis ay natauhan ako ukol sa ilang umiiral na kalagayan, sabay ukol sa aking pagka-walang-alam,-at nadama ko ang tawag ng meron, tawag na para bagang sinasabi: bigkasin mo ang talagang totoo...at kung binigkas ko: 'Ang umiiral na kalagayan ay laban sa dangal ng tao at hindi makatarungan at ang mismong meron na sitwasyon ay panawagan sa sipag at tiyaga upang baguhin,' - sa sandali ng pagbigkas, possible na, na may magsasabi na bulag o mali ako, o na mali ang aking mga iniisip na patakaran o na kapuri-puri ako. Nakataya ako." Ferriols, Pambungad sa Metapisika, 139.

122 Kincheloe, Critical Pedagogy Primer, 5.

(c) 2014 Franz Giuseppe F. Cortez

http://www.kritike.org/journal/issue 14/cortez june2014.pdf

ISSN 1908-7330
}

$(\mathrm{cc}) \mathrm{BY}-\mathrm{NC}$ 
Philippines, ed. by Bienvenido Lumbera et. al. (Quezon City: Ibon Books, 2007).

Calano, Mark, Interview with Franz Giuseppe Cortez, March 20, 2013.

Chomsky, Noam, Language and Responsibility, trans. by John Viertel (New York: Pantheon Books, 1977).

Constantino, Renato, Fetters on Tomorrow, ed. by Lourdes BalderramaConstantino (Quezon City: Karrel Inc., 1996).

Damo-Santiago, Corazon, A Century of Activism (Manila: Rex Books, 1972).

Darder, Antonia, Reinventing Paulo Freire: A Pedagogy of Love (Colorado: Westview Press, 2002).

Darder, Antonia, Marta Baltodano, and Rodolfo Torres, eds., The Critical Pedagogy Reader (New York: Routledge, c2009).

Dela Rosa, Rolando, Beginnings of the Filipino Dominicans (Quezon City: Dominican Province of the Philippines, 1990).

Fermon, Jan, "Who is Jose Ma. Sison?" In Jose Ma. Sison: A Celebration, ed. by Production Group, Aklat ng Bayan (Quezon City: Aklat ng Bayan, 2011).

Ferriols, Roque, "A Call for Cultural Realism: An Interview with Ferriols," by Ramon V. Puno and Vicente Cabanero, The Guidon, (December 11, 1968).

"A Memoir of Six Years," in Philippine Studies, 22:3-4 (1974), 338-

345.

Pambungad sa Metapisika (Quezon City: Ateneo Office for Research, 1991).

Freire, Paulo, Education for Liberation: Addresses by Paulo Freire and Critical Reflections on Indian Education (Bangalore: Ecumenical Christian Centre, 1975).

Teachers as Cultural Workers, trans. by Donaldo Macedo et. al.

(Colorado: Westview, 2005).

Pedagogy of Freedom: Ethics, Democracy and Civic Courage, trans.

by Patrick Clarke (Maryland: Rowman \& Littlefield Publishers, 1998). Pedagogy of Hope: Reliving Pedagogy of the Oppressed, trans. by

Robert R. Barr (New York: Continuum, 1995). Pedagogy of the City (New York: Continuum, 1993).

Pedagogy of the Heart, trams. by Donaldo Macedo and Alexandre

Oliveira (New York: Continuum, 1997).

"Some Issues: Neutrality, Respect for the Students, Epistemological Curiosity, and International Financial Aid," in Paulo Freire at the Institute, ed. by Maria de Figueiredo-Cowen and Denise Gastaldo (London: University of London, 1995). The Politics of Education: Culture, Power, and Liberation, trans. by Donaldo Macedo (Connecticut: Bergin \& Garvey Publishers, 1985).

(C) 2014 Franz Giuseppe F. Cortez http://www.kritike.org/journal/issue 14/cortez june2014.pdf ISSN 1908-7330 


\section{THOUGHTS OF ROQUE FERRIOLS}

Freire, Paulo, and Donaldo Macedo, Literacy: Reading the Word \& the World (Massachusetts: Bergin \& Garvey Publishers, 1987).

Freire, Paulo, and Ira Shor, A Pedagogy for Liberation: Dialogues on Transforming Education (London: MacMillan, 1987).

Garcia, Leovino Ma., "Fr. Roque J. Ferriols, S.J." in Loyola Schools Bulletin, November/December 2006, 2. Date Accessed: 16 March 2013.

Giroux, Henry A., Teachers as Intellectuals: Towards a Critical Pedagogy of Learning (Massachusetts: Bergin \& Garvey, 1988).

Theory and Resistance in Education: Towards a Pedagogy for the Opposition (Connecticut: Bergin \& Garvey, c2001).

Gonzales, Jboy, "Ang Wika ay Pagkakaibigan," in Faith of a Centurion: Homilies for Believers Willing to Take Risks, August 10, 2009. Date Accessed: 15 March 2013, <http://faithofacenturion.blogspot.com/ 2009/08/ang-wika-ay-pagkakaibigan.html>.

Guevara, Geoffrey A., "Si Ferriols sa Gilid." Paper presented at the Mid-Year Conference of the Philosophical Association of the Philippines, De La Salle University, Manila, Philippines, October 18, 2012.

Horkheimer, Max, Critical Theory: Selected Essays, trams. by Matthew J. O'Connell (New York: Continuum, 2002).

Irwin, Jones, Paulo Freire's Philosophy of Education: Origins, Developments, Impacts and Legacies (London: Continuum International Publishing, 2012).

Javier, Roberto, "Ututang Dila, Nagmamantika," in The Guidon, (August 21, 1969).

Jopson, Edgar, "Talumpati't Pagpupugay," in The Guidon, (August 21, 1969).

Joseph, John Earl, Language and Politics (Edinburgh: Edinburgh University Press, 2006).

Kincheloe, Joe, Critical Pedagogy Primer (New York: Peter Lang, 2008).

"Language Loss," in Sage Knowledge. Date Accessed: 16 March 2013, $<$ http://knowledge.sagepub.com/view/identity/n147.xml>.

May, Stephen, Language and Minority Rights: Ethnicity, Nationalism and the Politics of Language (New York: Routledge, 2012).

McCowan, Tristan, "Approaching the Political in Citizenship Education: The Perspectives of Paulo Freire and Bernard Crick," in Educate, 6:1 (2006), 57-70. Date Accessed: 17 January 2012, <http://www.educatejournal.org/index.php/educate/article/view/89/ 97>.

McLaren, Peter, "Critical Pedagogy: A Look at the Major Concepts," in The Critical Pedagogy Reader, ed. by Antonia Darder, Marta Baltodano and Rodolfo Torres (London: Routledge, 2003).

Montemayor, Leonardo Q., "Our Westernized View of Filipino Nationalism," in The Guidon, (January 30, 1969).

(c) 2014 Franz Giuseppe F. Cortez

http://www.kritike.org/journal/issue 14/cortez june2014.pdf

ISSN 1908-7330

(cc) BY-NC 
Montes, Vaughn F., "Pilipino Philosophy Course Reveals Important Insights," in The Guidon, (November 24, 1969).

Montiel, Cristina Jayme \& Evangelista, Susan, Down from the Hill: Ateneo de Manila in the First Ten Years under Martial Law, 1972-1982 (Quezon City: Ateneo de Manila University Press, 2005).

Nordquist, Richard, "Purism." Date Accessed: 15 March 2013, $<$ http://grammar.about.com/od/pq/g/purismterm.htm>.

Puno, Ramon V., "How 'Down from the Hill' Launched a Fruitful Dialogue on Filipinization," in The Guidon, (December 11, 1968).

Rodriguez, Agustin \& Que, Nemesio, eds., Pagdiriwang sa Meron: A Festival of Thinking Celebrating Fr. Roque J. Ferriols, S.J. (Quezon City: Ateneo de Manila University, 1997).

Schirmer, Daniel B., and Stephen Rosskam Shalom, eds., The Philippines Reader: A History of Colonialism, Neocolonialism, Dictatorship and Resistance (Cambridge: South End, 1987).

Simbulan, Dante, "A United Front for National Democracy," in An interview by Rigoberto D. Tiglao, The Guidon, (February 17, 1970).

Sunico, Ramon C, ed., University Traditions: The Humanities Interviews (Quezon City: Ateneo de Manila University, 2005).

Tsui, Amy \& Tollefson, James, eds., Medium of Instruction Policies: Which Agenda? Whose Agenda? (New Jersey: Lawrence Earlbaum Associates, 2004).

Wolf, Michael P. "Philosophy of Language," in Internet Encyclopedia of Philosophy, May 12, 2009. Date Accessed: 16 March 2013, $<$ http://www.iep.utm.edu/lang-phi/>. 